\title{
Actinomyces radingae
}

National Cancer Institute

\section{Source}

National Cancer Institute. Actinomyces radingae. NCI Thesaurus. Code C86113.

A species of anaerobic, Gram positive, rod shaped bacteria assigned to the phylum

Actinobacteria. This bacteria is alpha hemolytic, catalase and indole negative, hydrolyzes

esculin and does not reduce nitrate. A. rading ae infection is often associated with breast, chest, and back abscesses. 